\title{
Recent patent applications in genomics
}

\begin{tabular}{|c|c|}
\hline Patent \# & Subject \\
\hline & $\begin{array}{l}\text { DNA encoding human cathepsin } \mathrm{K} \text { - useful for diagnosing and } \\
\text { treating diseases associated with cathepsin } \mathrm{K} \text {, e.g., osteoporosis, } \\
\text { bone degradation, metastatic tumors, etc. }\end{array}$ \\
\hline
\end{tabular}

US 5691176 Cell line having a recombinant adeno-associated virus; comprises genomic AAV rep and cap genes and AAV/Epstein Barr virus vector.

WO 9743403 Cloning DNA into baculovirus which has a null mutation in essential gene; requires a cell containing rescue DNA providing the missing gene, used to express foreign proteins, for pest control, as vaccines, etc.

JP 9271383 Recombinant virus used as vaccine; comprises different exotic gene recombined to region nonessential to growth of chimera virus formed by genomic DNA.

US 5677143 DNA encoding human immunodeficiency virus binding protein TRP-185-useful to produce antibodies to diagnose or study epidemiology of acquired immunodeficiency syndrome.

WO 9735033 Nucleotide sequencing with ordered arrays of linear primers-useful to determine genetic variations associated with a disease, e.g., cystic fibrosis.

US 5670321 Sequencing of large DNA fragments by transposon-mediated sequencing of smaller subclones.

US 5670353 Expression of structural genes in plants using a subgenomic promoter and an activating domain of a positive-strand plant RNA virus.

US 5695977 Genomic integration of DNA by site directed recombinationusing construct containing recombination region homologous to consensus defined flanking region of short interspersed repeated DNA element.

WO 9732993 New nucleic acid encoding human chemotactic cytokine IIIused for treatment of e.g. tumors, infections, autoimmune diseases, etc.

WO 9732043 Identification of $E$. coli serotype $0157 \mathrm{H} 7$ by detection of specific DNA sequences-used for analysis of foods, clinical samples, medical products, etc.

WO 9732028 DNA containing a plant proto-porphyrinogen oxidase gene promoter-optionally linked to a heterologous gene, especially to express herbicide-resistant enzymes, and plants containing such constructs.

WO 9731098 Polypeptide encoding chemokine $\beta 4$ and monocyte chemotactic protein 4-useful to treat tumors, autoimmune disease, infection, asthma and fibrosis.

WO 9731012 New oligonucleotide primers amplifying gene regions conserved Univ. Michigan; among mammals-useful for developing genomic maps, isolating Michigan State Univ. clones and making cross-species comparisons.

WO 9730581 Induction or facilitation of male-sterility in plants by targeting genomic region corresponding to the MS5 locus or JAG18 gene of Arabidopsis thaliana.

WO 9730346 Separation and identification of fragments of genomic DNA by electrophoresis using porosity gradient coupled to gradient of chemical/thermal denaturant.

WO 9729193 Preparing nucleic acid encoding polyphenol oxidase by genomic DNA amplification; useful to control browning reactions in fruit and vegetables.

FR 2743367 Nucleic acid hybridizing specifically with genomic sequence of Staphylococcus pasteuri and derived primers and probes, for diagnostic detection and epidemiological studies.

\section{Assignee}

Human Genome Sciences

(Rockville, MD); The Institute

of Genomic Research

(Rockville, MD); Smithkline

Beecham (Philadelphia, PA)

Applied Immune Sciences

(Santa Clara, CA)

Boyce Thompson Inst.

(Ithaca, NY)

Japanese Geon Co. Ltd

Univ. of Texas System

Molecular Tool Inc.

(Baltimore, MD)

Mercator Genetics

(Menlo Park, CA)

Mycogen Plant Science

(San Diego, CA)

Genetic Info. Res. Inst.

Human Genome Sciences (Rockville, MD)

El Du Pont De Nemours

\& Co. (Wilmington, DE)

Novartis (Basel,

Switzerland)

Human Genome Sciences (Rockville, MD)

Gene Shears Pty Ltd (North Ryde, NSW, Australia)

Gelfi C; Righetti PG

Commonwealth Sci. \& Ind. Res. Org. (Australia)

Brun Y; Etienne J; Vandenesch F
$10 / 21 / 97$

Gaynor RB; Wu FK

$10 / 14 / 97$

Adams MD; Blake JA; 12/17/97

Debouck CM; Drake FH;

rald LM; Fraser CM;

Kirkness EF; Lee $\mathrm{NH}$;

Rood J; Drake F

Lebkowski JS;

$11 / 25 / 97$

(

Blissard GA;

$11 / 20 / 97$

Monsma SA

Boyce-Jacino M T;

$09 / 25 / 97$

Goelet P; Rogers Y

$09 / 23 / 97$

Ellis M; Kimmel BE;

Ruddy D

Ahlquist PG;

$09 / 23 / 97$

French RC

Jurka JW

$09 / 12 / 97$

A

Gentz RL; Ni J; Yu G

$09 / 12 / 97$

Jensen MA

$09 / 04 / 97$

A

Johnson MA:

09/04/97

A

Volrath SL; Ward ER

$08 / 28 / 97$

A

Adams M; Alderson

Applebaum E; $\mathrm{Li} \mathrm{H}$;

Li Y; Lima SH;

Parmelee D; White J

Brewer GJ; Venta PJ;

Yuzbasiyan-Gurkan V

$08 / 28 / 97$

A

Chaudhury AM; Craig S; 08/28/97

A

Dennis ES; Glover JA;

Grelon M; Dennis E

Gelfi C; Righetti PG

$08 / 21 / 97$

A

Robinson SP

$08 / 14 / 97$

A

Brun Y; Etienne J;

$07 / 11 / 97$

A tatus ${ }^{\star}$

A

